\title{
Does Radical-Right Success Make the Political Debate More Negative? Evidence from Emotional Rhetoric in German State Parliaments
}

\author{
Vicente Valentim $^{1}$ (D) Tobias Widmann ${ }^{1}$ (D) \\ Accepted: 3 March 2021 / Published online: 24 March 2021 \\ (c) The Author(s) 2021
}

\begin{abstract}
Political rhetoric has important effects on the quality of democracy, but we know very little about what causes variation in the tone of the political debate. We investigate how radical-right success affects the way the remaining politicians discuss political issues. Using an original dictionary, we measure different positive and negative emotions in a newly collected dataset of speeches in German state parliaments. Taking advantage of variation in the timing of elections when radical-right politicians enter these parliaments, we find that politicians of other parties respond to radical-right success by using more positive, instead of negative, emotions. The analyses suggest that this finding may be the result of a strategy by the remaining politicians to distance themselves from radical-right discourse. Our findings highlight how radical-right success can create incentives for other politicians to enforce democratic norms that radical-right politicians breach.
\end{abstract}

Keywords Negative political rhetoric $\cdot$ Emotions $\cdot$ Radical-right $\cdot$ Legislative behavior $\cdot$ Dictionary approaches $\cdot$ Germany

When they go low, we go high. Michelle Obama.

What explains variation in the overall tone of the political debate? A large body of research has shown that the communicative style with which the political debate is carried has crucial implications for democracy. Negative rhetoric can increase affective polarization (Iyengar et al., 2012), affect voter turnout (Ansolabehere et al., 1994; Lau \& Pomper,

A pre-registration of this study can be foundhttps://osf.io/hgrbn.

Vicente Valentim and Tobias Widmann contributed equally to the paper.

Vicente Valentim

vicente.valentim@eui.eu

Tobias Widmann

tobias.widmann@eui.eu

1 Department of Political and Social Sciences, European University Institute, Villa Sanfelice,

50014 San Domenico di Fiesole, Italy 
2001), and make minorities withdraw from public life (Hobbs \& Lajevardi, 2019). Despite these important consequences, we still know very little about what causes variation in the tone of the public debate.

We focus on how the success of radical-right politicians affects the political debate. Radical-right politicians are becoming increasingly successful across the world. Their success has been shown to shift the policy positions of the remaining candidates (Abou-Chadi \& Krause, 2018), polarize the electorate (Bischof \& Wagner, 2019), put new issues in the political agenda (Hobolt \& De Vries, 2015), and normalize previously stigmatized behavior (Bursztyn et al., 2017; Valentim, 2021). One of the most distinctive characteristics of radical-right candidates is their rhetoric, which makes extensive use of negative emotions (Widmann, 2021).

How does this success affect the rhetoric of the remaining politicians? We answer this question with resource to a newly-collected dataset of over 100,000 speeches in German state parliaments. We analyze these speeches using an original dictionary that measures the use of positive and negative emotions, specifically created to capture emotional language in German political text. Importantly, it allows us to measure different discrete emotions, instead of just positive and negative sentiment. We report a set of validation tests suggesting that our dictionary outperforms off-the-shelf dictionaries.

Taking advantage of variation in the timing of elections that granted representation in state parliaments to politicians of the radical-right party Alternative for Germany (AfD), we employ fixed-effects models to estimate the effect of radical-right success on the use of emotions by the remaining politicians. Our findings support a distancing effect: the success of radical-right politicians does not make the remaining politicians use more negative emotions, but it makes them use more positive emotions. This effect is large-between $50 \%$ and $100 \%$ of the baseline, depending on the outcome.

A set of additional quantitative and qualitative analyses suggest that the increasing use of positive emotions may be part of a strategy by which the remaining politicians build a contrast between themselves and the radical-right, who they call out on the breaching of established norms regulating the political debate. We start with quantitative analyses that test for two observable implications of the distancing mechanism. Supporting this mechanism we find that (1) the effect is stronger on mainstream politicians (as opposed to populist ones), who have a stronger incentive to portray themselves as guardians of norms breached by the radical-right; and that (2) among mainstream politicians, the effect is stronger for those left of center, whose values are more threatened by radicalright success. We also find evidence that the increased use of positive emotions by established politicians effectively counterbalances the increased negativity that the radical-right brings to the political debate, keeping it from becoming more negative overall.

We complement these tests with qualitative analyses of speeches in our data. We find ample evidence of politicians calling out the norm-breaching behavior of the radical right as unacceptable, marking a clear contrast between themselves and the radical-right, and mobilizing voters on the basis of opposition to radical-right rhetoric. 
These findings speak to three bodies of literature. In the first place, the paper relates to previous studies that have focused on how radical-right success affects the policy positions of the remaining candidates and parties (e.g. Abou-Chadi \& Krause, 2018; Bale, 2003). We add to this literature by looking into the effect of radical-right success on another crucial dimension of the political debate: the tone in which issues are debated.

In the second place, a growing strand of research has investigated the strategic usage of emotional language by political actors (Crabtree et al., 2020; Kosmidis et al., 2019; Müller, 2020). This study contributes to this research field by focusing on an additional factor that explains variation in the use of such language: the success of radical-right candidates.

Finally, a growing literature has focused on how norms regulating the political space can erode (Alvarez-Benjumea \& Winter, 2020; Bursztyn et al., 2017; Valentim, 2021). One central question in this literature has been the role of radicalright success in normalizing individual-level behavior associated with the radical right. Our paper adds to this literature by testing whether a similar effect can be found when drawing upon political elites, instead of citizens. Our findings suggest that, unlike citizens, politicians react to such success by holding closer to the norms breached by radical-right politicians.

\section{Radical-Right Success and the Political Debate}

We study how radical-right success affects the rhetorical style of the remaining politicians by looking into the case of Germany. The German party system was built upon a mixed member proportional system designed to keep a single dominant party from emerging (Lees, 2013, pp. 65-66). Based on a relatively low level of disproportionality, this system gave path to the emergence of a three-party system with centrist tendencies (Decker, 2014). Such system was composed of the Christian Democratic Party (CDU and its sister party in Bavaria, CSU), the main right-wing party; the Social Democrats (SPD), the main left-wing party; and the liberal party FDP. Following the rise to success of the Greens in the 1980s and, after the unification, the entry of the left populist party The Left (the successor of the ruling party in East Germany), the system ended up solidifying as a five-party system (Weldon \& Nüsser, 2010).

Radical-right parties traditionally did not enjoy significant success, failing to cross the electoral threshold of 5 percentage points. This situation changed in 2017, upon the first-time success of the radical-right party Alternative for Germany (AfD). This party had been founded in 2013 as a primarily Eurosceptic party. In the election of September that year, it narrowly missed the electoral threshold in the federal election, thus remaining out of parliament. The party then underwent a shift to the right, placing it at the rightmost position in the German political spectrum (Franzmann, 2019). An analysis of its manifestos and online statements portrays the AfD clearly at the far right of the ideological spectrum (Arzheimer, 2015). Its voters also resemble, in many ways, the supporters of radical-right parties in other countries (Arzheimer \& Berning, 2019; Goerres et al., 2018). In 2017, capitalizing on anxiety about 
migration and dissatisfaction with the German political establishment (Hansen \& Olsen, 2019), the AfD managed to acquire an impressive vote share of 12.6, winning 94 out of 709 parliamentary seats and becoming the third most voted party.

To derive expectations as to the effect of the parliamentary success of AfD politicians on the political rhetoric of the remaining politicians, our study builds on the literature on the use of emotional appeals by politicians and the literature on how established politicians react to the success of radical-right contenders. Previous studies on the effects of emotional appeals by politicians have shown such appeals to have a number of important effects (Ansolabehere et al., 1994; Brader, 2005; Brader et al., 2008; Iyengar et al., 2012; Lau \& Pomper, 2001; Rico et al., 2017; Valentino et al., 2008; Vasilopoulos et al., 2018, 2019; Valentino et al., 2011). Despite these important insights, this literature has mostly neglected that emotional appeals can also affect other politicians.

The success of radical-right politicians can be expected to significantly alter the use of emotions by established politicians. Previous research has shown that the remaining politicians tend to respond to their success by assuming more rightist policy positions (Abou-Chadi \& Krause, 2018). Radical-right politicians such as those belonging to the AfD, however, do not just innovate in the choice of issues they politicize or their position on those issues. Their rhetoric is also distinctive in that it tends to make more use of negative language (see Crabtree et al., 2020 for comparative evidence; Widmann, 2021 for evidence focused specifically on Germany). In facing the electoral success of these radical-right contenders, the remaining politicians can not only move their policy positions closer to those of the radical-right, but also try to emulate their discursive style.

Furthermore, the success of radical-right politicians can also affect the rhetoric of the remaining politicians via a process of social norm change. The political debate is regulated by norms that dictate which sets of behaviors are deemed appropriate (Mayntz, 1992). In observing that mainstream politicians tend to use positive emotions, MPs inclined to use negative emotional appeals in their discourse might refrain from doing so because that is not the modal form of communication in the political debate. Radical-right politicians may change this situation because of their characteristic norm-breaching rhetoric, which previous research has found to normalize stigmatized behavior (Bursztyn et al., 2017; Valentim, 2021). Social norms regulating the political debate are, in many ways, similar to the ones regulating other realms of social life (Bernick \& Wiggins, 1983), and hence one might expect radical-right success to erode them as well.

For these two reasons, one might expect radical-right discourse to make the remaining politicians use a more negative rhetoric. This leads us to formulate our first hypothesis:

Imitation hypothesis: The success of radical-right candidates will make other politicians use more negative emotions.

There are, however, reasons to expect the opposite effect as well. Established politicians may feel like radical-right contenders have ownership over the negative rhetoric they employ, making it a risky strategy to imitate it. A more profitable strategy may be for established politicians to reinvent themselves around the kind of rhetoric 
they have ownership on, such as their commitment to established values and norms (De Vries \& Hobolt, 2020, pp. 250-251). One way by which they can do so is to use an increasingly positive style of debating. That would allow them to build a clear contrast with the negative debate of the radical-right, and might signal their commitment to established norms that the radical-right openly breaches.

This distancing strategy may be rational due to its potential effect in containing the electoral wins of the radical-right. Negative emotions have been shown to affect a number of individual-level covariates that can make an individual more likely to cast a vote for the populist right (Rico et al., 2017; Vasilopoulos et al., 2018, 2019). This provides the remaining politicians with an incentive to respond to radical-right success by increasing their use of positive emotions to try and contain the effect that the negative rhetoric of the radical-right may have in fueling further support for it.

Such incentives, however, should not be homogeneous across politicians of the whole ideological spectrum. In the first place, the effect should be stronger on MPs of mainstream parties than on those of populist parties. Populist politicians of both the left and the right tend to use negative emotions as a ways of mobilizing on discontentment with the establishment (Crabtree et al., 2020)_a finding that has been replicated in the specific case of Germany (Widmann, 2021). As a consequence, unlike with mainstream parties, the increase in negativity brought about by the success of radical-right politicians may actually prove profitable to left populist politicians. In the German case, this means that the effect should be weaker on MPs of the left-populist party The Left, as compared to the remaining politicians.

Moreover, among mainstream parties, the effect should depend on the ideology of the politician. Left-wing politicians are the ones whose values are most threatened by radical-right discourse. Indeed, previous research has shown that, when political actors are successful in pushing for changes in the status quo, it is actors at the other end of the ideological spectrum who react by moving even farther in the opposite direction (Bustikova, 2014). Furthermore, the voters who support these politicians are also likely to be the ones who more strongly react by condemning radical-right discourse. As Bischof and Wagner (2019) show, after an initial legitimization effect, radical-right success leads to a backlash effect brought about by left-wing individuals becoming more likely to enforce the norms that the radical-right breaches. Consequently, left-wing mainstream politicians have stronger intrinsic (their own values) and strategic (their voters' reactions) motivations to distance themselves from the radical-right. This leads us to formulate our second hypothesis:

Distancing hypothesis: The success of radical-right candidates will make other politicians use more positive emotions. This effect should be stronger on politicians of mainstream parties and, among those, on politicians of the center-left. ${ }^{1}$

\footnotetext{
1 The second part of this hypothesis was not included in our pre-analysis plan, which made reference to the main effect alone. Moreover, the title of this hypothesis was slightly different in the pre-analysis plan. Appendix A in the Online Appendix lists these deviations from the pre-registration, along with the rationale for them.
} 
Table 1 Dates of German state elections included in the analyses

\begin{tabular}{llcl}
\hline State & Date of state election & Vote share for & Seats won by AfD \\
& & AfD & \\
\hline Baden-Württemberg & March 13, 2016 & 15.1 & $23 / 143$ \\
Bavaria & October 14, 2018 & 10.2 & $22 / 205$ \\
Berlin & September 18, 2016 & 14.2 & $25 / 160$ \\
Brandenburg & September 14, 2014 & 12.2 & $11 / 88$ \\
Bremen & May 10, 2015 & 5.5 & $4 / 83$ \\
Hamburg & February 15, 2015 & 6.1 & $8 / 121$ \\
Hessen & October 28, 2018 & 13.1 & $19 / 137$ \\
Lower Saxony & October 15, 2015 & 6.2 & $9 / 137$ \\
Mecklenburg-Vorpommern & September 4, 2016 & 20.8 & $18 / 71$ \\
North Rhine-Westphalia & May 14, 2017 & 7.4 & $16 / 199$ \\
Rhineland-Palatinate & March 13, 2016 & 12.6 & $14 / 101$ \\
Saarland & September 4, 2016 & 6.2 & $3 / 51$ \\
Saxony & August 31, 2014 & 9.7 & $14 / 126$ \\
Saxony-Anhalt & March 13, 2016 & 24.2 & $25 / 87$ \\
Schleswig-Holstein & May 7, 2017 & 5.9 & $5 / 73$ \\
Thuringia & September 14, 2014 & 10.6 & $11 / 91$ \\
\hline & & & \\
\hline & & &
\end{tabular}

\section{Data and Empirical Strategy}

As mentioned in the theory section, our empirical analyses draw upon the case of Germany. Doing so presents two main advantages. In the first place, it allows us to look into the case of a country that recently has witnessed the first-time success of the radical-right party AfD. In the second place, Germany is a federal state where each of the 16 states has its own parliament. The fact that elections for state parliaments are not synchronized allows us to estimate the effect of the parliamentary presence of radical-right politicians (coded as all politicians elected by the AfD) on the behavior of the remaining state MPs - a design that has been used in previous studies drawing upon different outcomes (De Vries \& Hobolt, 2020, pp. 204-220). Parliamentary entry is a standard measure of electoral success that has been used in a number of previous studies (e.g. Abou-Chadi \& Krause, 2018; Bischof \& Wagner, 2019). Table 1 shows the dates of the state elections included in our sample, along with the vote and seat share of the AfD in each of them.

The outcome variables in our empirical analyses are measured with resource to an original dataset composed of all speeches in the 16 German state parliaments between January 1, 2014 and June 1, 2019, collected from the official site of each state parliament. We include speeches both from MPs that were re-elected and from MPs who are in parliament only in part of the period covered by the analyses. ${ }^{2} \mathrm{We}$

\footnotetext{
2 To make sure this choice is not driving the results, Fig. D6 in the Online Appendix replicates the main analyses using only MPs that were re-elected. The results remain very similar to the main ones.
} 
removed speeches with length under 100 words, as these were mainly interjections and questions from the plenary audience rather than actual speeches. ${ }^{3}$ We only included speeches from major parties that are represented at the federal level. In addition, we excluded speeches from members of the state government and focus solely on MPs. This leaves us with a sample of 101,844 speeches.

We rely on parliamentary speeches as a data source because they represent the way politicians actually communicate during the political debate. We believe this approach to represent a better way of measuring the overall tone of the political debate than alternatives such as the use of party manifestos. While a readily available source of data, manifestos present the shortcoming of being released only in election years (Sagarzazu \& Klüver, 2017). They also include very low-salience topics, and have been shown to be inaccurate in measuring the ideological placement of parties (Dinas \& Gemenis, 2010).

Legislative speeches, on the other hand, have the potential to reach large audiences through mass media. Previous research has shown that speeches are a crucial means by which MPs are granted visibility in the media (Tresch, 2009). In Germany concretely, one of the largest newspapers (Frankfurter Allgemeine Zeitung) covers each plenary session of the German parliament since 1950 with at least one article in average (Proksch \& Slapin, 2012). TV programs also regularly pick up on (parts of) speeches in news shows (Salmond, 2014), which allows them to reach the larger television audience. Legislative speeches further have the advantage of providing individual-level data. While party manifestos, press releases, or official media statements only allow for the analysis of party-level variation, legislative speeches can reveal within-party differences in political debate (Hjorth, 2020; Proksch \& Slapin, 2012). This allows us to build a panel-like dataset where we observe the emotional tone of the same individual legislator across time - and, crucially, before and after the parliamentary entry of the AfD. Finally, unlike party manifestos, which are written before the elections, parliamentary speeches are more adaptive to contextual changes - in this case, the parliamentary entry of radical-right MPs.

To measure how much these speeches make use of positive and negative emotions, we rely on a dictionary approach. We use a novel emotional dictionary ("ed8") that has been specifically created to measure discrete emotional language, while taking into consideration German language peculiarities. It should be noted that this dictionary was designed having in mind the specific aim of analyzing political text. The ed8 dictionary is based on the augmented dictionary (Rauh, 2018), a German sentiment dictionary that reliably discriminates positive and negative tone in German political language. However, the augmented dictionary cannot differentiate between discrete emotions - which is important since different emotions (even of the same valence) can differently affect information processing, attitude formation, and the behavior of voters (Rico et al., 2017; Valentino et al., 2008, 2011; Vasilopoulos

\footnotetext{
3 To make sure this decision is not driving the results, Fig. D7 in the Online Appendix replicates the main analyses without removing these speeches.
} 
et al., 2019; Vasilopoulou \& Wagner, 2017). We thus extended this dictionary with separate categories that attribute words to eight different emotions. ${ }^{4}$

The emotions under scrutiny include five basic emotions (anger, fear, disgust, sadness, and joy) as defined by Ekman (1999). To these, three additional emotions (pride, enthusiasm, and hope) were added given their central role in political discourse (Brader \& Marcus, 2013). The measurement of different discrete emotions is crucial given that they have diverging political consequences, often explained by underlying appraisal patterns. Appraisals are the dimensions by which individuals evaluate events eliciting emotional responses (Lazarus, 1991). While some emotions differ in terms of pleasantness (anger versus joy), others vary in the level of certainty or situational control that is associated with them (enthusiasm versus hope) (Lazarus, 1991; Smith \& Ellsworth, 1985; Tiedens \& Linton, 2001). Furthermore, emotions can also differ in their temporal perspective, focusing either on the presence/past (joy) or on the future (enthusiasm, hope). These differences in appraisal patterns are reflected in the selection of vocabulary included in the different emotional categories of the ed8 dictionary. For instance, while positive emotions all include positive terms, enthusiasm includes more future-oriented vocabulary. In turn, hope includes positive terms that are associated with more uncertainty, as compared to joy and enthusiasm.

To check whether this approach is accurate, we used a German crowd working platform called Crowdguru, which is similar to Amazon's Mechanical Turk. Online Appendix B describes the crowd coding process, quality tests, and the comparison to other freely available dictionaries in detail. Overall, the results show that the novel ed8 dictionary applied in this study outperforms widely used off-the-shelf dictionaries in several measures across all comparable emotions. It shows robust F1 scores and substantially improves the accuracy of automated text classification compared to other emotional dictionaries.

Applying the ed8 to the data provides a score measuring how many words associated with each emotions are found in a given parliamentary speech. For example, a document containing four anger words and two words connected to joy, obtains a value of 4 for anger and 2 for joy. To create comparable scores independent of the length of a given document, normalized emotional scores are created, i.e. dividing the emotional scores by the word count of each document. These normalized scores were then standardized to make comparisons easier. These final standardized scores for each of the eight emotional categories constitute the outcome variables in our analyses. Table D1 in the Online Appendix shows how the emotions correlate in the speeches that compose our dataset. Figure D1 in the Online Appendix shows the distribution of these eight outcome variables. ${ }^{5}$ In the case of both positive and negative emotions, we also include a summary index as an outcome, which we obtain from

\footnotetext{
${ }^{4}$ Further details on the process of construction of the dictionary and how it adds to existing dictionaries can be found in Appendix B.

5 As this figure shows, the distribution of the outcome variables is rather skewed. For this reason, Fig. D10 in the Online Appendix presents a robustness check using the log-transformation of the dependent variables. The results remain substantively similar to the main ones.
} 
extracting the first principal component of the individual standardized emotion. In so doing, we hope to reduce noise and lower concerns with multiple hypotheses testing. 6

This data set was then grouped by thirty-day periods, centered around the date of the state election in their country. In this final data set, the unit of observation is the politician*month-to-election $(n=37,289)$. This means that our data set gives us information on the average level of emotions used by each MP in their speeches, within a given number of months before or after the state election. ${ }^{7}$

Our empirical analyses rely on models with politician fixed-effects that estimate the effect of the parliamentary presence of radical-right MPs (coded as AfD politicians) on the remaining politicians. ${ }^{8}$ A potential concern with one-way fixed-effects models is that there may be periodic fluctuation in the level of emotionality as a function of the distance to the election. Specifically, one might suspect that campaign periods have a level of emotionality that is different from the remaining periods, as research has shown that politicians change their rhetorical strategy in the weeks ahead of elections (Ceccobelli, 2018). For this reason, we rely on two-way fixed effects models including month-to-election fixed effects that control for common trends in the level of emotionality for each actor as we move closer and farther from the date of the election. The treatment effect is then calculated according to the following equation:

$$
Y_{i t}=\alpha+\gamma_{i}+\lambda_{t}+\tau D_{i t}+u_{i t}
$$

where $Y_{i t}$ is the level of the dependent variable in speech $i$ at time period $t ; \gamma_{i}$ is a vector of politician-level fixed effects that control for unobserved heterogeneity across MPs; $\lambda_{t}$ is a vector of month-to-election fixed effects; and $\tau$ is the treatment effect.

It should be noted that this design makes two assumptions. In the first place, in controlling for the distance to the election, we assume that all time-variant confounders that may affect the relation we are interested in are a function of the distance to the election. We keep this model as the main one because it is the one we pre-registered. Still, in the Online Appendix (Fig. D2), we relax this assumption by replicating the analyses including controls for the calendar month in which each speech took place. In the second place, we assume that there are no spillover effects. In other words, we expect the success of radical-right politicians in one state not to affect the political rhetoric in other states. To check if this assumption is met, Fig. D12 presents a placebo test that replicates the analyses shown in Fig. 2 but using dates of elections in other states as the date of the treatment. We find no clear

\footnotetext{
6 Tables D4 through D7 show the PCA results.

7 We also replicate the analyses without grouping the data by monthly periods. In these analyses, we simply group the data by day and then add the month-to-election fixed effects as in the main model shown in Fig. 2. As shown in Fig. D8, the results remain very similar.

${ }^{8}$ Figure D9 in the Online Appendix shows that the results remain very similar if we estimate the model with state fixed effects instead of politician fixed effects.
} 

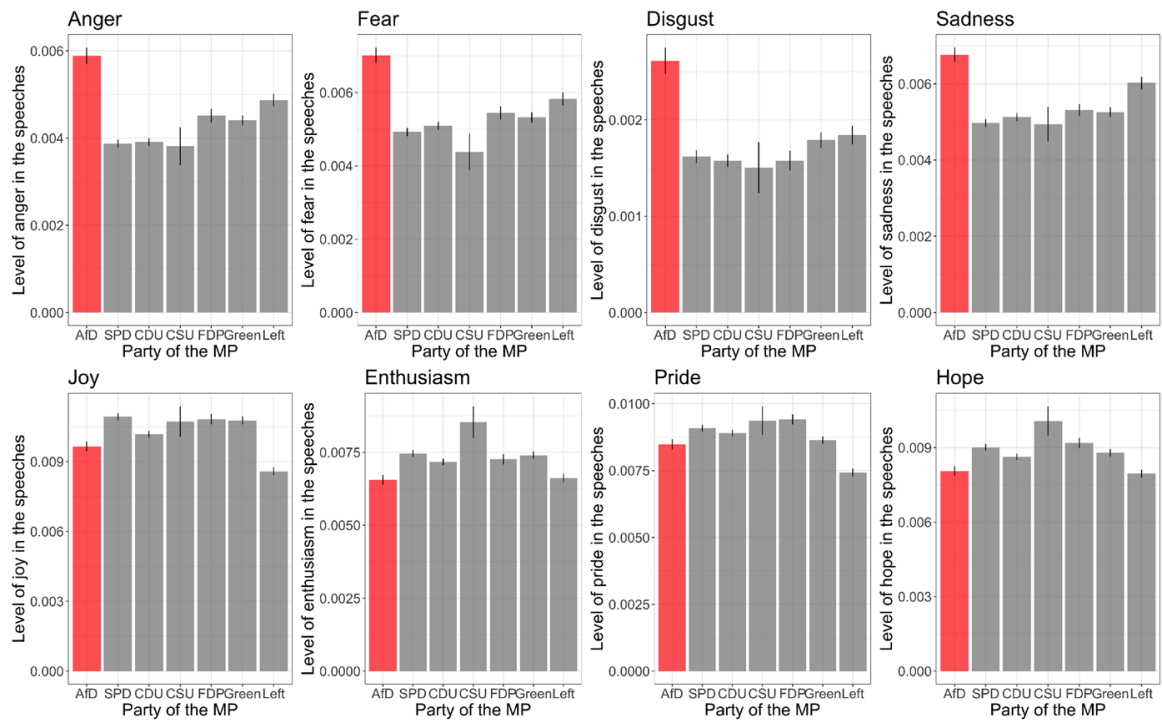

Notes: Lines represent 95\% Confidence Intervals..

Fig. 1 Use of different emotions in parliamentary speeches, conditional on the party of the MP. Lines represent $95 \%$ confidence intervals

evidence of spillovers. The effects are small, mostly non-significant, and often contradictory across models.

\section{Findings}

Before we estimate the effect of the presence of radical-right politicians in state parliaments, we check whether there is indeed a descriptive difference in use of emotions between politicians of the radical-right and the remaining ones. Fig. 1 plots the mean score for each emotion in MP speeches of each of the main German parties. As the figure makes clear, radical-right politicians (those who belong to the party AfD) tend to use significantly more negative emotions in their rhetoric than do their counterparts from other parties. When we turn to positive emotions, the pattern is the opposite: radical-right MPs are among the ones using positive emotions less often. The only other party whose MPs use a similarly low amount of positive emotions is the left-populist The Left. This finding is in line with previous research, which has found that populist politicians use positive emotions less often than the mainstream ones (Widmann, 2021), and that the rhetoric of parties far from the ideological center also tends to be less positive (Crabtree et al., 2020). ${ }^{9}$

\footnotetext{
${ }^{9}$ One might argue that this difference is instead explained by the size of the party. Our assertion that this difference is based on the populist character is based on the work by Widmann (2021), who finds that populist politicians use more negative emotional appeals. This study draws upon the case of Germany, using a very similar time period to the one in our study. Moreover, it should be noted that the AfD and
} 


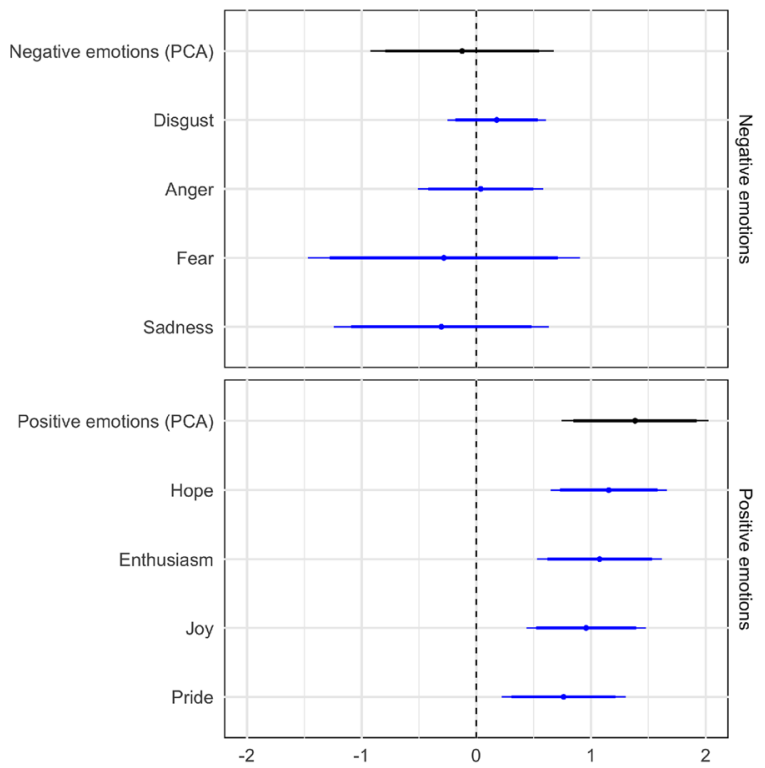

Notes: Thick lines represent 95\% Confidence Intervals; thin lines represent $90 \%$ Confidence Intervals. All dependent variables are standardized. The models include actor-level and months-since-election fixed effects. Standard errors are clustered by actor.

Fig. 2 Effect of the parliamentary presence of radical-right MPs on the use of emotional appeals by the remaining MPs

We now turn to estimating the effect of radical-right success on the rhetoric of the remaining politicians. Figure 2 shows the effect of the parliamentary presence of radical-right MPs on the emotional appeals made by state MPs of other parties. It shows clear support for the distancing hypothesis, to the detriment of the imitation hypothesis. The parliamentary presence of radical-right MPs increases the use of positive emotions by MPs of the remaining parties; but has no effect on their use of negative emotions.

Footnote 9 (continued)

The Left were not, in the period included in our sample, the smallest parties among the ones shown in Fig. 1. For a long portion of the period included in our sample, the AfD was the third biggest party in Germany, just below CDU and SPD. As for The Left, it enjoyed a similar level of popular support to that of FDP and the Greens. On the other hand, in Austria and Switzerland, the two populist parties FPÖ and SVP also use more negative emotional language (Widmann, 2021), even though they represent some of the biggest parties in their respective countries and have been or still are members of the government. This being said, while the idea that extremist parties tend to employ a more negative rhetoric than centrist parties is based on previous literature, it should be noted that the descriptive analyses shown in this figure do not allow us to know distinguish between extremism on the left-right scale and the outsider character of the AfD and Die Linke. In other words, the more extremist parties in Germany are also the ones with less probability of entering government. 
The effects on positive emotions are large in substantive terms-ranging between around .8 standard deviations in the case of pride and around 1.4 standard deviations in the case of the summary measure. When compared to the baseline, the magnitude of the unstandardized effects is also remarkable. Tables D2 and D3 show the unstandardized effects and the summary statistics of the outcome variables in the control group (observations in parliaments without radical-right politicians in parliament). The comparison of the two tables shows that our effects range between around $50 \%$ (in the case of pride) and around 100\% of the baseline (in the case of hope). As we have noted, previous research has found that mainstream politicians tend to employ a more positive rhetoric than politicians from challenger parties (Crabtree et al., 2020; Widmann, 2021). This might make it harder to find an effect of radical-right success due to ceiling effects. The fact that, despite that, we find such large effects, makes the magnitude of the effects all the more remarkable.

Looking at the effect on each individual emotion also shows interesting patterns. The stronger effects are on hope and enthusiasm. As shown in Fig. 1, these are the emotions that radical-right politicians themselves tend to use less often. The fact that the remaining politicians respond to radical-right success by increasing these emotions suggests that they may do so with the aim of creating a sharp distinction between their rhetoric and that of the radical-right. At the same time, both of these emotions tend to be used for electoral mobilization (Brader, 2005; Just et al., 2007), suggesting that politicians may increase their use of positive emotions as a ways of mobilizing voters against the newly successful radical-right and the negativity of its discourse. We explore this mechanism in further detail in the next section. That the effect is stronger on these two emotions further highlights the importance of looking into different discrete emotions, since differences in their patterns can point towards the mechanism behind one's empirical findings.

The Online Appendix provides a number of other robustness checks and additional analyses. Figures D3 and D4 show little evidence of heterogeneity depending on the government or opposition status of the MP's party. Figure D5 shows that the main effect can be replicated both in states where AfD speeches are more frequent than the median and in states where they are less frequent than the median. Figure D11 presents a placebo using the election in Hessen in 2013. In this election, the AfD narrowly failed to enter parliament. As such, it represents a good placebo test to check whether the results are indeed driven by the parliamentary entry of radicalright politicians, or if these changes in emotionality happen after each state election. Finally, Fig. D13 shows the results of a robustness check where we replicate the analyses after sequentially removing each state from the sample.

\section{Creating Distance Towards Radical-Right Politicians? Investigating the Mechanism}

\section{Quantitative Analyses}

In the previous section we found that, while the parliamentary presence of radicalright MPs does not affect the extent to which MPs of the remaining parties use 


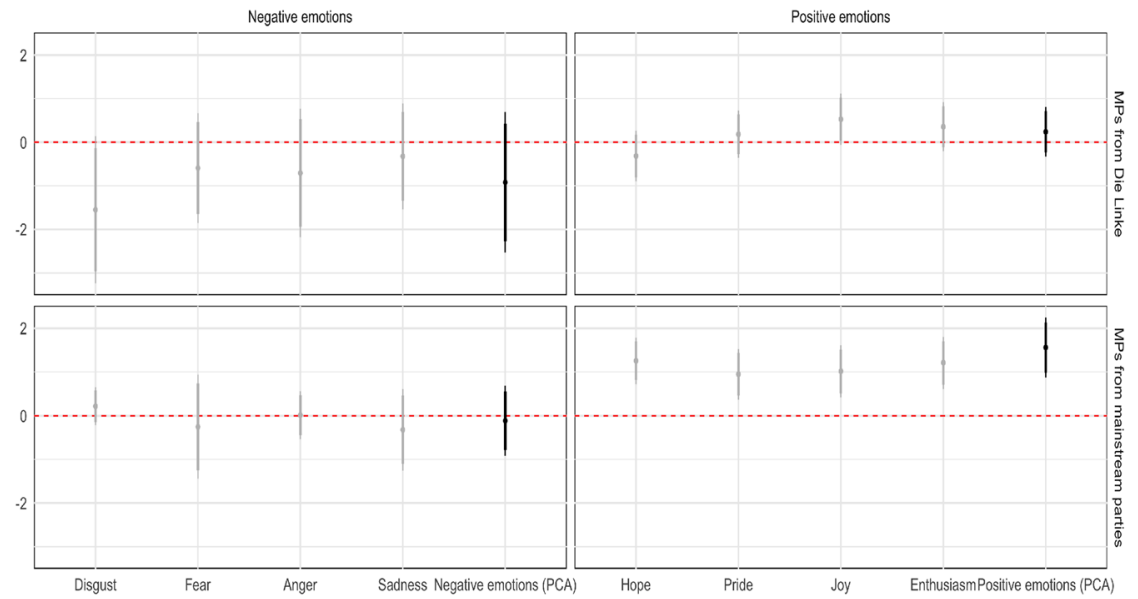

Notes: Thick lines represent 95\% Confidence Intervals; thin lines represent $90 \%$ Confidence Intervals. All dependent variables are standardized. The models include actor-level and months-since-election fixed effects. Standard errors are clustered by actor.

Fig. 3 Effect on radical left party The Left and on mainstream parties

negative emotions in their speeches, it increases their use of positive emotionsespecially hope and enthusiasm. As we have argued in the theoretical section, a possible explanation for this finding is that MPs of the remaining parties increase their use of positive emotions to distance themselves from radical-right discourse.

If this is the mechanism in place we should find the effect to be stronger on MP's of mainstream parties-who have more to lose from an increase in the overall negativity of the political debate than do their counterparts from populist parties, who likely profit from this increased negativity. In the case at hand, this means that the effect should be weaker on MP's of the populist left party The Left. On the other hand, among mainstream parties, the effect should be stronger on left-wing MPs, because their values are more affected by the divisive negative discourse of the radical-right and because their voters also tend to react to radical-right success by holding closer to the norms breached by the radical-right.

To test whether the effect is stronger on MPs of mainstream parties than on their counterparts from populist parties, we replicate the main analyses shown in Fig. 2 on two sets of subsamples: MPs of the populist party The Left; and MPs of mainstream parties-CDU and CSU, SPD, FDP, and Greens. ${ }^{10,11}$ We would expect the

\footnotetext{
10 The coding of the Greens as a mainstream party as opposed to a radical-left party might raise some concerns. However, this party is much more institutionalized than Green parties in other countries and is one of the Green parties in Europe that has deviated the most from the typical model of the party family (Carter, 2013). To make sure this choice is not driving the results, in the Online Appendix we replicate these analyses excluding the Greens. As shown in Fig. D14, the results remain very similar.

${ }^{11}$ While we do focus on individuals MPs, previous research provides us with good reasons to believe that the behavior of German MPs should be affected by their party affiliation (Proksch \& Slapin, 2012).
} 


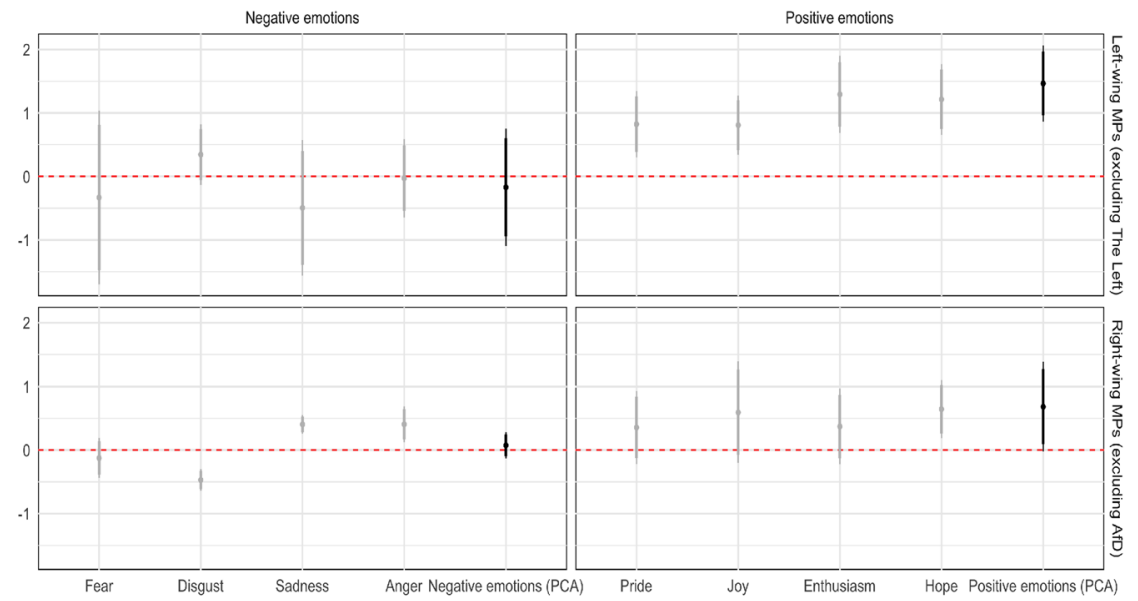

Notes: Thick lines represent 95\% Confidence Intervals; thin lines represent $90 \%$ Confidence Intervals. All dependent variables are standardized. The models include actor-level and months-since-election fixed effects. Standard errors are clustered by actor.

Fig. 4 Effect conditional on the ideology of the MPs

effect to be much smaller on MPs of the populist party The Left, the descendant of the ruling party in former East Germany.

The results of these analyses are shown in Fig. 3. Supporting the strategic distancing mechanism, the figure shows a clear difference between MPs from The Left party and those from mainstream parties. The effects are much weaker for MPs of The Left party (upper panel in the figure) than for MPs of mainstream parties (lower panel in the figure).

We now look at the second empirical implication of the distancing mechanismthat, amid mainstream politicians, the effect should be stronger on those left-ofcenter. To do so, we replicate the analyses on another two subsamples composed of MPs from left-wing parties and MPs from right-wing parties. Because we are interested in mainstream politicians, we remove the party The Left from these analyses. ${ }^{12}$ Thus, we consider as left-wing MPs those who belong to the Greens and the SPD (Social Democrats). We consider as right-wing MPs those who belong to CDU/ CSU (Christian Democrats) and FDP (market liberals). As with the main analyses, we remove MPs from the AfD from these subsample analyses. Figure 4 shows the results of these analyses. We find a pattern similar to the one shown in Fig. 2 in both subsamples. The success of radical-right politicians increases the use of positive emotions by both left- and right-wing MPs. Supporting the distancing mechanism, however, the effects on the use of positive emotions are stronger for left-wing MPs (upper panel on the figure), than for right-wing MPs (lower panel on the figure). For

\footnotetext{
12 To make sure this decision is not driving the results, Fig. D14 in the Online Appendix replicates these analyses including MPs from The Left in the subsample of left-wing MPs. The difference between leftand right-wing politicians is still clear, even if slightly smaller than the one shown in Fig. 4 below-as one would expect, considering that Fig. 3 showed no effect on MPs of The Left.
} 


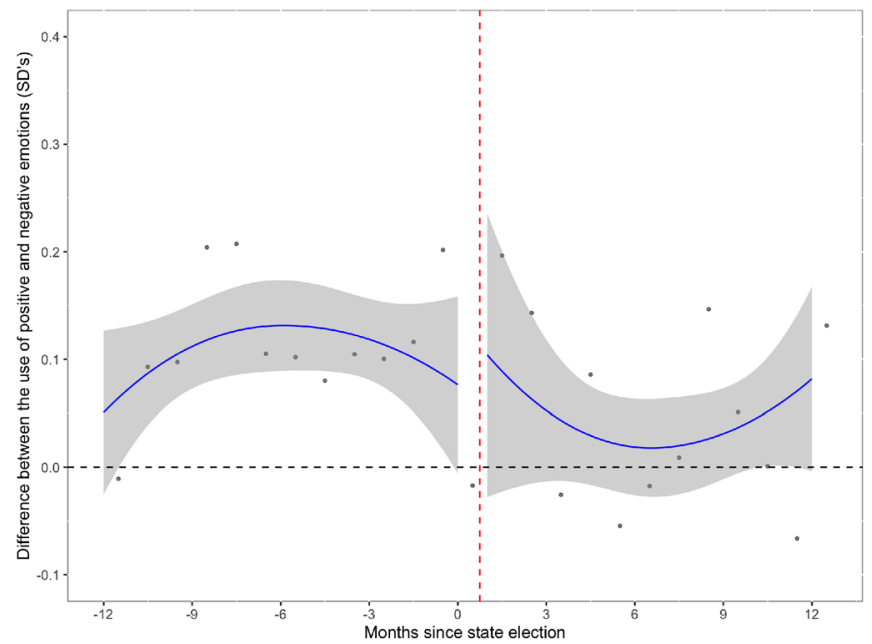

Notes: Dashed area represents 95\% Confidence Intervals. Values represent the difference in the values of PCA's for positive emotions and those of the PCA for positive emotions: higher values in this variable mean that the debate has an overall more positive tone; lower values in this variable mean that the debate has an overall more negative tone. Points represent local averages.

Fig. 5 Does the overall tone of the debate change? Differences in the use of positive and negative emotions as a function of distance to the state elections

most positive emotions, the coefficient size for left-wing politicians are around twice as large as those for right-wing politicians.

One question that is raised by these findings is whether this increase in the use of positive emotions is sufficient to make up for the increased negativity that radical-right politicians bring to the debate. To investigate this question, we create a variable that gives us the difference in the values of PCA for negative emotions and those of the PCA for positive emotions. Positive values in this variable mean that the debate has an overall positive tone; negative values mean that the debate has an overall negative tone. Since we are interested in evaluating whether the remaining politicians can counter the negativity brought about by the parliamentary entry of the radical-right, we do not remove AfD politicians from these analyses. We then look at the evolution of this variable before and after the state elections that brought the radical-right to parliament.

The results of this exercise are shown in Fig. 5. As the figure shows, there is no significant discontinuity in the difference between the use of positive and negative emotions after the state elections that bring the radical-right to parliament. These descriptive trends seem to suggest that, in using more positive emotions as a response to the success of the radical-right, the remaining politicians are able to compensate for the negativity that radical-right politicians bring to the debate. 


\section{Qualitative Analyses}

If the results are indeed driven by a conscious strategy by MPs to distance themselves from the radical-right rhetoric, we should find evidence of that strategy by looking into the speeches in qualitative fashion. To check for this, we draw upon a subsample of the speeches in our data that makes the amount of data manageable. Since our results show an increased use of positive emotions as a consequence of radical-right success, we start with taking the pool of speeches in our data that have a very high level of each of the positive emotions-values above twice the mean of each emotion - from the post-election period, by politicians who are not from the AfD, but which refer to the AfD. From this pool, we randomly choose a subsample of 400. After removing speeches from members of state government, as in our main analyses, we end up with a total of 361 speeches, which we look into in qualitative fashion. We draw upon a sample of highly emotional speeches because we are interested in looking for patterns that may explain why MPs react to radical-right success by increasing their use of positive emotions. This being said, it should be noted that this subsample represents a most-likely-case scenario, whose analyses may be biased in the favor of the hypotheses of the paper.

Anecdotally, in these speeches we do find many examples of MPs calling out the negative, norm-breaching discourse of the radical-right as something new and unacceptable, that was detrimental to healthy democratic debate. This suggests that the remaining politicians are aware of how negative discourse of the radical-right breaches established norms regulating the political debate.

We also find many instances of politicians building a stark contrast between such discourse and that of their own party. In so doing, they often present themselves as the enforcers of the norms that this discourse breaches, claiming that they will fight to keep such norms from eroding. This contrast between the radical-right politicians, breaching established norms, and one's own party is often accomplished by using emotional appeals.

Finally, reinforcing the idea that the use of positive emotions is strategic, we also find instances of politicians explicitly calling for voters to mobilize against the norm-breaching rhetoric of the radical right—and using positive emotions to do so. They seem to make particular use of enthusiasm and hope to this end. This finding is consistent with the quantitative finding that these two emotions were the ones whose use increases the most after the radical-right enters parliament. As we have mentioned in the results section, this is in line with previous research that has shown that these emotions are frequently used to mobilize voters. Appendix E provides speeches that exemplify all these points.

To check whether these anecdotes represent a larger pattern in our data, we conduct more systematic qualitative analyses. Following a deductive approach, we manually code each speech in this subsample for whether the speaker reacts to radicalright success and rhetoric in the ways outlined in the anecdotes above, and which are relevant to our argument: reacting to radical-right success and rhetoric by calling out their general style of doing politics; by calling out their debating style in parliament specifically; and by building a contrast between the style of radical-right politicians and that of the speaker's party. Within each of these three categories, we also code 
Table 2 Frequency of reactions to the success and rhetoric of AfD politicians

\begin{tabular}{llll}
\hline Category & Description & $\begin{array}{c}\text { Absolute } \\
\text { fre- } \\
\text { quency }\end{array}$ & Proportion \\
\hline Criticizing general style & $\begin{array}{l}\text { MPs call out the general way AfD MPs do politics as } \\
\text { unacceptable }\end{array}$ & 168 & .47 \\
Criticizing debating style & $\begin{array}{l}\text { MPs call out the debating style of AfD politicians as } \\
\text { unacceptable } \\
\text { MPs draw a clear opposition between their party's } \\
\text { actions and those of AfD politicians }\end{array}$ & 105 & .29 \\
Criticizing policy & MPs disagree with policies being proposed by AfD & 96 & .40 \\
\hline
\end{tabular}

the reason why MPs react to the radical-right in this way. These are provided in the Appendix F. To put these values into perspective, we also code reactions that criticize radical-right policy instead of their rhetoric. In so doing, we hope to have a baseline against which to compare our values.

Table 2 shows the results of these analyses. The most frequent reaction among these four is to call out the general political style of the AfD as unacceptable-a reaction which we find in almost half the speeches analyzed. This is followed by the building of contrast between AfD politicians and the speaker and her party. As detailed in Appendix F, the main ways by which politicians mark contrast involve the use of positive emotions. Calling out of the debating style of AfD politicians in parliament is a reaction found in $29 \%$ of the speeches. It may be argued that it is rather unsurprising that politicians react to the success of a new party by disagreeing with it. However, we find the proportions of each reaction quite impressive, considering that we only find criticism of policy-which should happen quite often in parliamentary debates-in $26 \%$ of the speeches analyzed.

Figure D16 in the Online Appendix reports a test for an alternative mechanism: that the results may be driven by radical-right politicians giving more importance to issues which the remaining politicians talk more positive about. Our evidence does not support this alternative mechanism.

\section{Conclusion}

The way mainstream politicians react to the strategy of their niche challengers is what makes or breaks the success of such strategy (Meguid, 2005). Existing literature has provided extensive evidence that, when it comes to policy positions, mainstream politicians tend to react to the threat posed by radical-right contenders by coming closer to their position. Our results suggest that this is not the case when it comes to the tone of the discourse. While the rhetoric of radical-right politicians is characterized by extensive use of negative emotions, their success increases the use of positive emotions by the remaining politicians. A mix of quantitative and qualitative analyses suggest this is a means by which politicians 
create a contrast between the radical-right, breaching established norms, and themselves, enforcers of those norms.

One possible explanation for this difference is that mainstream politicians follow different strategies in different dimensions of their electoral appeal. They may adopt increasingly rightist policy positions as a ways of trying to appeal to radical-right voters; and, at the same time, call out their negative rhetoric as unacceptable to try and keep their traditional constituencies. This can represent a strategy of "parroting the pariah", whereby established politicians come closer to the positions of extremist contenders but ostracize them at the same time (Van Spanje \& de Graaf, 2018).

Our results also run contrary to a body of research showing that radical-right success can normalize behavior and preferences associated with the far right (Bischof \& Wagner, 2019; Bursztyn et al., 2017; Valentim, 2021). The likely explanation for this difference lies in the different incentives facing citizens and politicians. For citizens, radical-right success can present an opportunity to publicly reveal previously stigmatized preferences (Valentim, 2021). For politicians, instead, it can present an opportunity to highlight their commitment to democratic norms in an effort to mobilize voters.

On the other hand, our findings are in line with previous research in highlighting how politicians tend to use emotional language strategically (Crabtree et al., 2020; Kosmidis et al., 2019; Müller, 2020). However, our paper adds an important insight to this conclusion. As our findings suggest, the emotional appeals used by different politicians change depending on who their challengers are and how electorally successful they become. Concretely, the success of candidates whose rhetoric is deemed unacceptable increases the incentives to use emotions as a tool to mobilize voters against such rhetoric.

One question raised by this conclusion is to what extent these findings are likely to travel beyond the German case. Democracies tend to create norms against parties with affinities to previous dictatorships (Dinas \& Northmore-Ball, 2019). This is even more likely in Germany, given the particularly devastating consequences of the Nazi regime the country witnessed. The creation of strong norms against rhetoric associated with radical-right politicians might force established politicians to respond to their success with clear differentiation. This being said, we believe the findings are not simply a product of the specific characteristics of the German case. Empirical findings from Denmark show a similar strategy with members of parliament distancing themselves rhetorically by portraying cooperation with a radicalright party as morally objectionable (Hjorth, 2020). One can also find even anecdotal evidence of such strategies in other contexts. In Spain, the incumbent party PSOE reacted to the successful radical-right Vox by stressing its leftist position and the party's role in the Spanish transition to democracy (De Vries \& Hobolt, 2020, pp. 250-251). During the US Presidential Campaign of 2016, Hillary Clinton refused time and time again to give in to the negative rhetoric of Donald Trump which, like in our data, she called out as unacceptable.

Overall, our findings highlight how electoral competition can push mainstream politicians to distance themselves from the rhetorical style of the radical-right. As the qualitative examples provided in the Appendix E show, radical-right success 
often impels the remaining politicians to mobilize voters on an opposition to the norms that are breached by the newly successful contenders. While radical-right rhetoric is in many ways damaging to democracy - in their perpetuation of stereotypes about minority groups, spread of fake news, or negative discourse-our results suggest that their success can create incentives for other politicians to distance themselves from negativity of radical-right rhetoric. In so doing, they may be able to mitigate part of these negative consequences. Given that negative debating has been associated with detrimental outcomes such as affective polarization (Iyengar et al., 2012), this finding carries important implications for the quality of democracy. In increasing the use of positive instead of negative emotions, mainstream politicians do not feed potential loops of negativity that could be very detrimental to the process of public deliberation.

Supplementary Information The online version of this article (https://doi.org/10.1007/s11109-02109697-8) contains supplementary material, which is available to authorized users.

Acknowledgements We thank Daniel Bischof, Francesco Colombo, Catherine De Vries, Elias Dinas, Miriam Golden, Jonne Kamphorst, Joe Kendall, Christina la Cour, Levente Littvay, Sergi Martínez, Kasia Nalewajko, Fred Paxton, Ana Ruipérez Núñez, Judith Spirig, António Valentim, Annabelle Wittels, Eleanor Florence Woodhouse, and the Political Behavior reviewers and editor for extremely helpful comments on earlier versions of the manuscript. The data and code to replicate the analyses of the article can be found at the Political Behavior Dataverse.

Funding Open access funding provided by European University Institute - Fiesole within the CRUICARE Agreement.

Open Access This article is licensed under a Creative Commons Attribution 4.0 International License, which permits use, sharing, adaptation, distribution and reproduction in any medium or format, as long as you give appropriate credit to the original author(s) and the source, provide a link to the Creative Commons licence, and indicate if changes were made. The images or other third party material in this article are included in the article's Creative Commons licence, unless indicated otherwise in a credit line to the material. If material is not included in the article's Creative Commons licence and your intended use is not permitted by statutory regulation or exceeds the permitted use, you will need to obtain permission directly from the copyright holder. To view a copy of this licence, visit http://creativecommons.org/licen ses/by/4.0/.

\section{References}

Abou-Chadi, T., \& Krause, W. (2018). The causal effect of radical right success on mainstream parties' policy positions: A regression discontinuity approach. British Journal of Political Science. https:// doi.org/10.1017/S0007123418000029.

Alvarez-Benjumea, A., \& Winter, F. (2020). The breakdown of anti-racist norms: A natural experiment on normative uncertainty after terrorist attacks. SSRN Scholarly Paper ID 3537597. Social Science Research Network. https://papers.ssrn.com/abstract=3537597.

Ansolabehere, S., Iyengar, S., Simon, A., \& Valentino, N. (1994). Does attack advertising demobilize the electorate? American Political Science Review, 88(4), 829-838.

Arzheimer, K. (2015). The AfD: Finally a successful right-wing populist eurosceptic party for Germany? West European Politics, 38(3), 535-556.

Arzheimer, K., \& Berning, C. C. (2019). How the Alternative for Germany (AfD) and their voters veered to the radical right, 2013-2017. Electoral Studies, 60, 102040. http://www.sciencedirect.com/scien ce/article/pii/S0261379418305158. 
Bale, T. (2003). Cinderella and her ugly sisters: the mainstream and extreme right in Europe's bipolarising party systems. West European Politics, 26(3), 67-90.

Benoit, K., Conway, D., Lauderdale, B. E., Laver, M., \& Mikhaylov, S. (2016). Crowd-sourced text analysis: Reproducible and agile production of political data. American Political Science Review, 110(2), 278-295.

Bernick, E. L., \& Wiggins, C. W. (1983). Legislative norms in eleven states. Legislative Studies Quarterly, 8(2), 191-200.

Bischof, D., \& Wagner, M. (2019). Do voters polarize when radical parties enter parliament? American Journal of Political Science, 63(4), 888-904.

Brader, T. (2005). Striking a responsive chord: How political ads motivate and persuade voters by appealing to emotions. American Journal of Political Science, 49(2), 388-405.

Brader, T., \& Marcus, G. E. (2013). Emotion and political psychology. In L. Huddy, D. O. Sears, \& J. S. Levy (Eds.), The Oxford handbook of political psychology. Oxford University Press.

Brader, T., Valentino, N. A., \& Suhay, E. (2008). What triggers public opposition to immigration? Anxiety, group cues, and immigration threat. American Journal of Political Science, 52(4), 959-978.

Bursztyn, L., Egorov, G., \& Fiorin, S. (2017). From extreme to mainstream: How social norms unravel. Tech. rep. National Bureau of Economic Research. https://www.nber.org/papers/w23415.

Bustikova, L. (2014). Revenge of the radical right, revenge of the radical right. Comparative Political Studies, 47(12), 1738-1765.

Carter, N. (2013). Greening the mainstream: Party politics and the environment. Environmental Politics, 22(1), 73-94.

Ceccobelli, D. (2018). Not every day is Election Day: A comparative analysis of eighteen election campaigns on Facebook. Journal of Information Technology \& Politics, 15(2), 122-141.

Crabtree, C., Golder, M., Gschwend, T., \& Indridason, I. H. (2020). It is not only what you say, it is also how you say it: The strategic use of campaign sentiment. The Journal of Politics, 82(3), 1044-1060.

De Vries, C. E., \& Hobolt, S. (2020). Political entrepreneurs: The rise of challenger parties in Europe. Princeton, NJ: Princeton University Press.

Decker, F. (2014). Follow-up to the Grand Coalition: The German party system before and after the 2013 federal election. Berghahn Journals, German Politics and Society, 32(2), 19-40.

Dinas, E., \& Gemenis, K. (2010). Measuring parties' ideological positions with manifesto data: A critical evaluation of the competing methods. Party Politics, 16(4), 427-450. https://doi.org/10.1177/13540 68809343107.

Dinas, E., \& Northmore-Ball, K. (2019). The ideological shadow of authoritarianism. Comparative Political Studies. https://doi.org/10.1177/0010414019852699.

Ekman, P. (1999). Basic emotions. In Handbook of cognition and emotion (Vol. 98, pp. 45-60). Wiley.

Franzmann, S. T. (2019). Extra-parliamentary opposition within a transforming political space: The AfD and FDP under Merkel III between 2013 and 2017. German Politics, 28(3), 332-349.

Goerres, A., Spies, D. C., \& Kumlin, S. (2018). The electoral supporter base of the alternative for Germany. Swiss Political Science Review, 24(3), 246-269.

Grimmer, J., \& Stewart, B. M. (2013). Text as data: The promise and pitfalls of automatic content analysis methods for political texts. Political Analysis, 21(3), 267-297.

Guinjoan, M. (2014). Parties, elections and electoral contests: Competition and contamination effects. Ashgate Publishing Ltd.

Hansen, M. A., \& Olsen, J. (2019). Flesh of the same flesh: A study of voters for the alternative for Germany (AfD) in the 2017 federal election. German Politics, 28(1), 1-19.

Hjorth, F. (2020). Establishment responses to populist radical right challenges: The politics of moral distancing: 47. https://files.osf.io/v1/resources/drmhu/providers/osfstorage/5d07236ba844d40017c0 b56e? action=download\&direct\&version $=6$.

Hobbs, W., \& Lajevardi, N. (2019). Effects of divisive political campaigns on the day-to-day segregation of Arab and Muslim Americans. American Political Science Review, 113(1), 270-276.

Hobolt, S. B., \& De Vries, C. E. (2015). Issue entrepreneurship and multiparty competition. Comparative Political Studies, 48(9), 1159-1185.

Iyengar, S., Sood, G., \& Lelkes, Y. (2012). Affect, not ideology: Social identity perspective on polarization. Public Opinion Quarterly, 76(3), 405-431.

Just, M. R., Crigler, A. N., \& Belt, T. L. (2007). Don't give up hope: Emotions, candidate appraisals, and votes. In W. R. Neuman, G. E. Marcus, A. N. Crigler, \& M. MacKuen (Eds.), The affect effect: Dynamics of emotion in political thinking and behavior. University of Chicago Press. 
Kosmidis, S., Hobolt, S. B., Molloy, E., \& Whitefield, S. (2019). Party competition and emotive rhetoric. Comparative Political Studies, 52(6), 811-837.

Lau, R. R., \& Pomper, G. M. (2001). Effects of negative campaigning on turnout in US Senate elections, 1988-1998. Journal of Politics, 63(3), 804-819.

Lazarus, R. S. (1991). Emotion and adaptation. Oxford University Press.

Lees, C. (2013). Christian Democracy is dead; long live the Union parties: Explaining CDU/CSU dominance within the German Party System. German Politics, 22(1-2), 64-81.

Lehmann, P., \& Zobel, M. (2018). Positions and saliency of immigration in party manifestos: A novel dataset using crowd coding. European Journal of Political Research, 57(4), 1056-1083.

Mayntz, R. (1992). Social norms in the institutional culture of the German Federal Parliament. In Theory of culture (pp. 219-240). University of California Press.

Meguid, B. M. (2005). Competition between unequals: The role of mainstream party strategy in niche party success. American Political Science Review, 99(3), 347-359.

Meier, T., Boyd, R. L., Pennebaker, J. W., Mehl, M. R., Martin, M., Wolf, M., \& Horn, A. B. (2019). "LIWC auf Deutsch": The development, psychometrics, and introduction of DE-LIWC2015. PsyArXiv. https://doi.org/10.17605/OSF.IO/TFQZC.

Mikolov, T., Chen, K., Corrado, G., \& Dean, J. (2013). Efficient estimation of word representations in vector space. arXiv:1301.3781[cs].

Mohammad, S. M., \& Turney, P. D. (2010). Emotions evoked by common words and phrases: Using mechanical turk to create an emotion lexicon. In Proceedings of the NAACL HLT 2010 workshop on computational approaches to analysis and generation of emotion in text (pp. 26-34). Association for Computational Linguistics.

Müller, S. (2020). The Temporal Focus of Campaign Communication. Unpublished manuscript. https:// muellerstefan.net/papers/journal_of_politics_mueller.pdf

Pennebaker, J. W., Mehl, M. R., \& Niederhoffer, K. G. (2003). Psychological aspects of natural language use: Our words, our selves. Annual Review of Psychology, 54(1), 547-577.

Proksch, S.-O., \& Slapin, J. B. (2012). Institutional foundations of legislative speech. American Journal of Political Science, 56(3), 520-537.

Proksch, S.-O., Lowe, W., Wäckerle, J., \& Soroka, S. (2019). Multilingual sentiment analysis: A new approach to measuring conflict in legislative speeches. Legislative Studies Quarterly, 44(1), 97-131.

Rauh, C. (2018). Validating a sentiment dictionary for German political language — a workbench note. Journal of Information Technology \& Politics, 15(4), 319-343.

Rico, G., Guinjoan, M., \& Anduiza, E. (2017). The emotional underpinnings of populism: How anger and fear affect populist attitudes. Swiss Political Science Review, 23(4), 444-461.

Roberts, M. E., Stewart, B. M., \& Tingley, D. (2014). stm: R package for structural topic models. Journal of Statistical Software, 10(2), 1-40.

Rudkowsky, E., Haselmayer, M., Wastian, M., Jenny, M., Emrich, Š, \& Sedlmair, M. (2018). More than bags of words: Sentiment analysis with word embeddings. Communication Methods and Measures, 12(2-3), 140-157.

Sagarzazu, I., \& Klüver, H. (2017). Where have all the leaders gone? Evaluating the dynamics of parties' issue attention in coalition governments. Social Science Quarterly, 98(3), 1045-1060.

Salmond, R. (2014). Parliamentary question times: How legislative accountability mechanisms affect mass political engagement. The Journal of Legislative Studies, 20(3), 321-341.

Smith, C. A., \& Ellsworth, P. C. (1985). Patterns of cognitive appraisal in emotion. Journal of Personality and Social Psychology, 48(4), 813.

Tausczik, Y. R., \& Pennebaker, J. W. (2010). The psychological meaning of words: LIWC and computerized text analysis methods. Journal of Language and Social Psychology, 29(1), 24-54.

Tiedens, L. Z., \& Linton, S. (2001). Judgment under emotional certainty and uncertainty: The effects of specific emotions on information processing. Attitudes and Social Cognition, 16, 331-345.

Tresch, A. (2009). Politicians in the Media: Determinants of legislators' presence and prominence in Swiss newspapers. The International Journal of Press/Politics, 14(1), 67-90.

Valentim, V. (2021). Parliamentary representation and the normalization of radical right support. Comparative Political Studies. https://doi.org/10.1177/0010414021997159.

Valentino, N. A., Brader, T., Groenendyk, E. W., Gregorowicz, K., \& Hutchings, V. L. (2011). Election night's alright for fighting: The role of emotions in political participation. The Journal of Politics, 73(1), 156-170. 
Valentino, N. A., Hutchings, V. L., Banks, A. J., \& Davis, A. K. (2008). Is a worried citizen a good citizen? Emotions, political information seeking, and learning via the internet. Political Psychology, 29(2), 247-273.

Van Spanje, J., \& de Graaf, N. D. (2018). How established parties reduce other parties' electoral support: The strategy of parroting the pariah. West European Politics, 41(1), 1-27.

Vasilopoulos, P., Marcus, G. E., \& Foucault, M. (2018). Emotional responses to the Charlie Hebdo attacks: Addressing the authoritarianism puzzle. Political Psychology, 39(3), 557-575.

Vasilopoulos, P., Marcus, G. E., Valentino, N. A., \& Foucault, M. (2019). Fear, anger, and voting for the far right: Evidence from the November 13, 2015 Paris terror attacks. Political Psychology, 39(3), $557-575$.

Vasilopoulou, S., \& Wagner, M. (2017). Fear, anger and enthusiasm about the European Union: Effects of emotional reactions on public preferences towards European integration. European Union Politics, $18(3), 382-405$.

Weldon, S., \& Nüsser, A. (2010). Bundestag election 2009: Solidifying the five party system. German Politics and Society, 28(3), 47-64.

Widmann, T. (2021). How emotional are populists really? Factors Explaining emotional appeals in the communication of political parties. Political Psychology, 42(1), 163-181.

Zittel, T., \& Gschwend, T. (2008). Individualised constituency campaigns in mixed-member electoral systems: Candidates in the 2005 German Elections. West European Politics, 31(5), 978-1003.

Publisher's Note Springer Nature remains neutral with regard to jurisdictional claims in published maps and institutional affiliations. 